Małgorzata KIRSCHENSTEIN, Kamil KRASUSKI, Artur GOŚ

Military University of Aviation (Lotnicza Akademia Wojskowa)

\title{
MONITORING THE VECTOR ERROR BETWEEN A REFERENCE STATION AND A GNSS ON-BOARD RECEIVER IN THE GBAS SYSTEM IN THE POLISH AIR TRANSPORT
}

\section{Monitoring błędu wektora pomiędzy stacją referencyjną a pokładowym odbiornikiem GNSS w systemie GBAS w transporcie lotniczym w Polsce}

\begin{abstract}
The article presents research results concerning the determination of the vector error between a reference station and the GNSS on-board receiver in the GPS satellite measurements for GBAS system, taking into account the ZTD troposphere delay parameter. Based on the conducted studies, it was found that the highest value of the vector error between a reference station and the GNSS on-board receiver can exceed $0.18 \mathrm{~m}$, for a distance of over $40 \mathrm{~km}$ and the ZTD value equalling to $2428.1 \mathrm{~mm}$. The error results of vector measurement can be used in the RTK-OFT differential technique in the GBAS system.

Keywords: GPS, GBAS system, flight test, vector (baseline) error, ZTD parameter

Streszczenie: Artykut przedstawia wyniki badań dotyczacych określenia błędu wektora pomiędzy stacja referencyjna a pokładowym odbiornikiem GNSS w pomiarach satelitarnych GPS dla systemu wspomagania GBAS, przy uwzględnieniu parametru opóźnienia troposferycznego ZTD. Na podstawie przeprowadzonych badań stwierdzono, że najwyższa wartość błędu wektora pomiędzy stacja referencyjna a pokładowym odbiornikiem GNSS wynosić może ponad 0,18 m, przy odległości ponad $40 \mathrm{~km}$ i wartości ZTD równej 2428,1 mm. Wyniki błędu pomiaru wektora moga zostać wykorzystane wzastosowaniu techniki różnicowej RTK-OTF w systemie GBAS.
\end{abstract}

Słowa kluczowe: GPS, system GBAS, test lotniczy, błąd wektora, parametr ZTD 


\section{Introduction}

The future of aviation, including Polish aviation, is to develop and implement the GBAS system, particularly an approach procedure [2]. A solution for the GBAS system in aviation entails the development of a specialized technical infrastructure at airports. This involves the installation of a network of reference stations with satellite GNSS receivers [4, 6]. GNSS reference stations must be dual-frequency and at least two-system, for example, GPS/GLONASS. This is to control the obtained satellite data in the event of a shutdown of one of the GNSS navigation systems. In Poland, a solution for a reference station network is the ASG-EUPOS system, which was originally designed for geodesic purposes [3]. However, in accordance with the agreement between the Surveyor General of Poland and the Polish Air Navigation Services Agency, the GNSS sensor was to be available and exploited in air navigation [14]. As long as the GNSS sensor is used for positioning in Poland within the framework of the GPS, GLONASS and SBAS (EGNOS) satellite navigation, until the present moment, no scheme of the implementation of the GNSS sensor for the GBAS augmentation in Polish aviation has been developed [15, 16]. The GBAS system performs numerous functions. For geodesy needs, the GBAS allows [10]: a designation of coordinates of a GNSS reference station with high precision and accuracy, permanent monitoring of GNSS reference station coordinates, monitoring of the multi-path effect, monitoring signal noise to ratio, determining the elevation and azimuth of the GNSS satellites, monitoring the ephemeris data and GNSS satellite clock, monitoring the transfer of time. For the needs of aviation, the GBAS system allows [8]: continuous monitoring of the atmosphere (ionosphere and troposphere), verification of data quality of the GNSS positioning, determining continuity, integrity, availability and accuracy of the GNSS sensor in aviation, transferring differential corrections from the reference station to an on-board GNSS receiver, accurate time references in GNSS, determination of velocity and of acceleration of moving objects against ground stations.

In the framework of the GBAS system, the parameters of the ionospheric delay are designed in the form of the VTEC parameter - Vertical TEC [9] and of the tropospheric delay in the form of the ZTD parameter - Zenith Troposphere Delay [12]. This paper presents research findings with regard to the measurement of the impact of the ZTD value upon designating vector values (baseline) in the GBAS system, between a reference station and an on-board GNSS receiver. The work exploits real observation and GPS navigation data derived from an experimental flight over the aerodrome in Dęblin. The value of the ZTD tropospheric delay will be designated for the baseline: reference station-on-board GNSS receiver. The work is experimental in its nature and may prove crucial for the implementation of the GBAS system in Polish aviation. Therefore, the presented research methodology can be used for monitoring the condition of the troposphere over a selected aerodrome in Poland. Thus, the concept of the research work is of key importance for civil and military aviation. 


\section{Research method}

The mathematical model of the dependence of the ZTD tropospheric correction on determining the reference station-aircraft position is defined in the GBAS augmentation system in air transport. This mathematical dependence can be described as follows [1]:

$$
\frac{d r}{r}=\frac{Z T D}{R \cdot \cos z}
$$

where:

$d r$ - vector error (baseline): accuracy of vector measurement in differential GNSS positioning (expressed in meters), $r$ - baseline between a reference station and a GNSS onboard receiver (expressed in meters), ZTD - Zenith Troposphere Delay (expressed in millimetres), $R$ - Earth radius, $R=6371 \mathrm{~km}, z$ - zenith angle (expressed in degrees).

After a transformation, we ultimately receive:

$$
d r=\frac{Z T D \cdot r}{R \cdot \cos z}
$$

The formula of equation (1) is used to determine the accuracy of the vector measurement of the reference station-aircraft, hence determining the aircraft positioning accuracy in the GBAS augmentation system. It should be noted that dependence (1) determines aircraft positioning accuracy in the horizontal plane for LNAV navigation. In equation (1), the variable parameters are: baseline (vector) $r$, tropospheric delay parameter $Z T D$, parameter of the zenith angle $z$.

The dependence of equation (1) must be determined for a given GNSS observation interval in the GBAS system, e.g. every $1 \mathrm{sec}$.

\section{Research experiment}

In the research test, the authors performed a number of practical experiments to determine the effect of the ZTD parameter upon the baseline length: reference station - GNSS onboard receiver. In the research, the authors applied real source materials from the air experiment of a Cessna 172 flight above Dęblin aerodrome. In addition, on the flight route, three reference stations were assembled: Base, VirA and VirB. On this basis, it was possible to determine a baseline between particular reference stations and the GNSS on-board receiver. Moreover, for each reference station, the authors designed the ZTD tropospheric delay parameter, exploiting the dual-frequency PPP accurate positioning method. The position of the Cessna 172 and the reference stations was determined by means of the PPP method, using GPS code-phase observations. The calculations were performed for a onesecond interval. A trajectory of the Cessna 172 against the location of reference stations is shown in fig. 1. Ultimately, the flight trajectory and the position of the reference stations 
were determined in fig. 1 in the ellipsoidal BLh coordinates (B - Latitude, L - Longitude, $\mathrm{h}$ - ellipsoidal height). Coordinates B and $\mathrm{L}$ in fig. 1 are expressed in degrees.

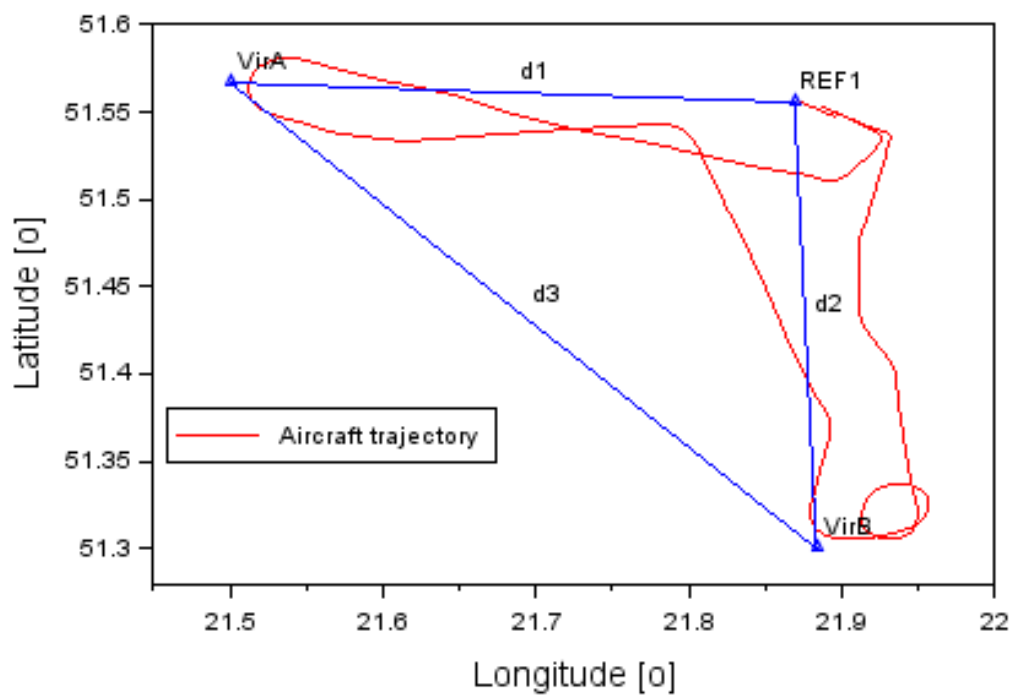

Fig. 1. The aircraft trajectory with the background of reference stations location [based on Scilab software]

In the case of the ZTD tropospheric delay parameter, the calculations were made by independent geodetic software: APPS, developed by JPL LAC Analysis Centre [7]. The software is available as a computation interface on the website: https://apps.gdgps.net/ apps/apps_file_upload.php [17]. In the above-mentioned geodetic programme, the ZTD parameter is determined from the PPP method in the stochastic process. The computation interval was set at $1 \mathrm{~s}$. Moreover, when determining the ZTD parameter in a stochastic process, it is modelled by means of the random walk hypothesis, in the least-squares method, in a sequential solution [11]. Finally, the ZTD parameter is defined as a sum of the following factors [13]:

$$
Z T D=Z H D+Z W D
$$

where: $Z H D$ - Zenith Hydrostatic Delay (expressed in millimetres), $Z W D$ - Zenith Wet Delay (expressed in millimetres).

In the PPP method, the ZHD parameter is modelled as a deterministic part, while the $Z W D$ parameter as a stochastic part. The sum of parameters $Z H D$ and $Z W D$ leads to the final $Z T D$ tropospheric product. 


\section{Results}

The research was started with a determination of the baseline (vector) between each reference station and a GNSS on-board receiver as follows:

$$
r=\left\{\begin{array}{l}
r_{\text {Cessna-Base }} \\
r_{\text {Cessna-VirA }} \\
r_{\text {Cessna-VirB }}
\end{array}\right.
$$

where:

$r_{\text {Cessna-Base }}$ - baseline Base-Cessna reference station, $r_{\text {Cessna-VirA }}$ - baseline reference station VirA-Cessna, $r_{\text {Cessna-VirB }}$ - baseline reference station-VirB Cessna.

Next, the ZTD parameter values, for each reference station, were determined individually, using the PPP method. Hence, the ZTD parameter was defined as:

$$
Z T D=\left\{\begin{array}{l}
Z T D_{\text {Base }} \\
Z T D_{\text {VirA }} \\
Z T D_{\text {VirB }}
\end{array}\right.
$$

where:

$Z T D_{\text {Base }}$ - determined $Z T D$ value for base reference station, $Z T D_{\text {VirA }}$ - determined $Z T D$ value for VirA reference station, $Z T D_{V i r B}$ - determined $Z T D$ value for VirB reference station.

In the next stage, the authors determined the maximum values of the zenith angle $z$, as:

$$
z=\left\{\begin{array}{l}
85^{\circ} \\
80^{\circ} \\
75^{\circ}
\end{array}\right.
$$

where:

$85^{\circ}$ - value of zenith angle, $80^{\circ}$ - value of zenith angle, $75^{\circ}$ - value of zenith angle.

The obtained results are presented in figs. 2-7, developed in Scilab v.6.0.0 software [18].

Figure 2 shows the results of determining the measurement error of the baseline between the base reference station and a GNSS on-board receiver. The measurement vector values are presented in the function of the ZTD parameter. It can be concluded that the biggest measurement error of vector $r_{\text {Cessna-Base }}$ arises when the ZTD is equal to $2436.7 \mathrm{~mm}$. Then, for the zenith angle $z=85^{\circ}$, the parameter $d r$ exceeds $0.124 \mathrm{~m}$. Moreover, at $z=80^{\circ}$, the $d r$ is equal to $0.062 \mathrm{~m}$. In addition, at $z=75^{\circ}$, the vector error $d r$ equals $0.042 \mathrm{~m}$. It is worth 
adding that the average value of the error of vector $d r$ for the zenith angle $z=85^{\circ}$ equals $0.044 \mathrm{~m}$, and for the angle $z=80^{\circ}$ it is equal to $0.022 \mathrm{~m}$, whereas for the zenith angle $z=75^{\circ}$, it is $0.015 \mathrm{~m}$.

Figure 3 shows the results of designating the measurement error of vector $r_{\text {Cessna-Base }}$ in the function of distance: reference station - GNSS on-board receiver. The greatest vector error for the baseline $r_{\text {Cessna-Base }}$ is visible when the value $r_{\text {Cessna-Base }}$ exceeds $28 \mathrm{~km}$. The dependence of the vector error $d r$ on its length $r_{\text {Cessna-Base }}$ is a linear dependence, as shown in fig. 3. The minimum error value of the vector $d r$ is visible when the distance $r_{\text {Cessna-Base }}$ is equal to approximately $0.1 \mathrm{~km}$. In fig. 3 , it is possible to observe that an increase in the zenith angle for large distances $r_{\text {Cessna-Base }}$ has a direct impact on the results of the parameter $d r$.

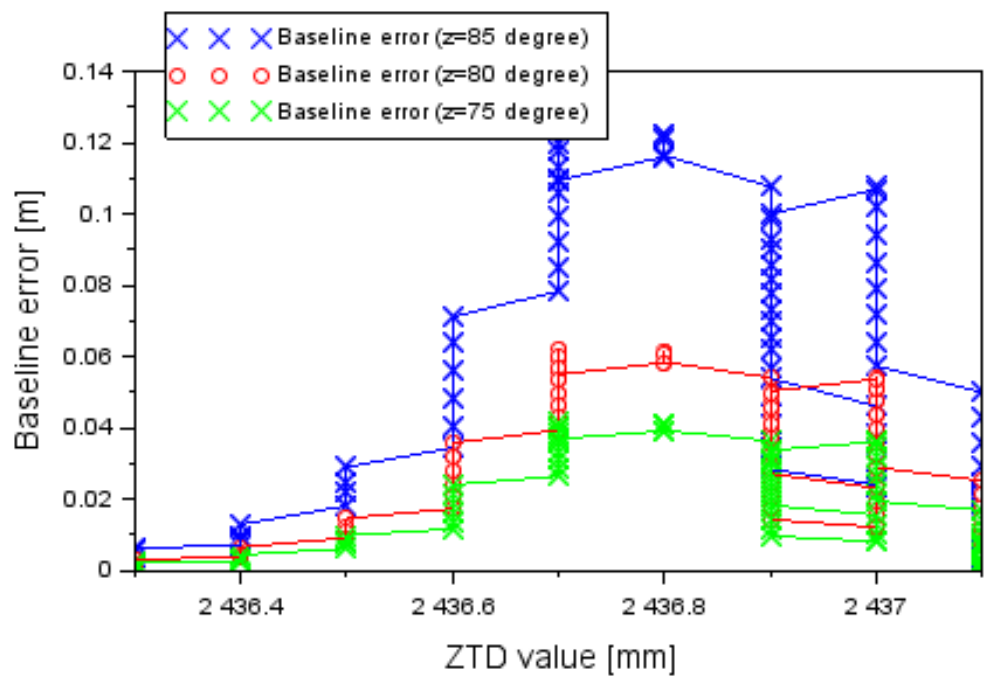

Fig. 2. The baseline error as a function of $Z T D$ parameter for vector of base reference station-Cessna aircraft [based on Scilab software]

Figure 4 shows the results of determining the baseline measurement error between the reference station VirA and the GNSS on-board receiver. The values of the measurement error of vector are presented in the function of the ZTD parameter. It can be concluded that the biggest measurement error of vector $r_{\text {Cessna-VirA }}$ arises when the ZTD is equal to $2428.1 \mathrm{~mm}$. Then, for the zenith angle $z=85^{\circ}$, the parameter $d r$ exceeds $0.183 \mathrm{~m}$. Moreover, at $z=80^{\circ}$, the $d r$ is equal to $0.092 \mathrm{~m}$. In addition, at $z=75^{\circ}$ the vector error $d r$ is equal to $0.062 \mathrm{~m}$. It is worth adding that the average value of the error vector $d r$ for the zenith angle $z=85^{\circ}$ equals $0.112 \mathrm{~m}$, and for the angle $z=80^{\circ}$ it is equal to $0.056 \mathrm{~m}$, whereas for the zenith angle $z=75^{\circ}$, it is $0.038 \mathrm{~m}$.

Figure 5 shows the results of determining the measurement error of vector $r_{\text {Cessna-VirA }}$ in the distance function: reference station - GNSS on-board receiver. The biggest 
measurement error of the vector for the baseline $r_{\text {Cessna-VirA }}$ is visible when the value $r_{\text {Cessna-VirA }}$ exceeds $42 \mathrm{~km}$. The dependence of the vector error $d r$ on its length $r_{\text {Cessna-VirA }}$ is a linear relationship, as shown in fig. 5. The minimum value of the error of vector $d r$ is visible when the distance $r_{\text {Cessna-VirA }}$ is equal to approximately $1.3 \mathrm{~km}$. In fig. 5 , it can be observed that an increase in the zenith angle for large distances $r_{\text {Cessna-VirA }}$ has a direct impact on the results of the parameter $d r$.

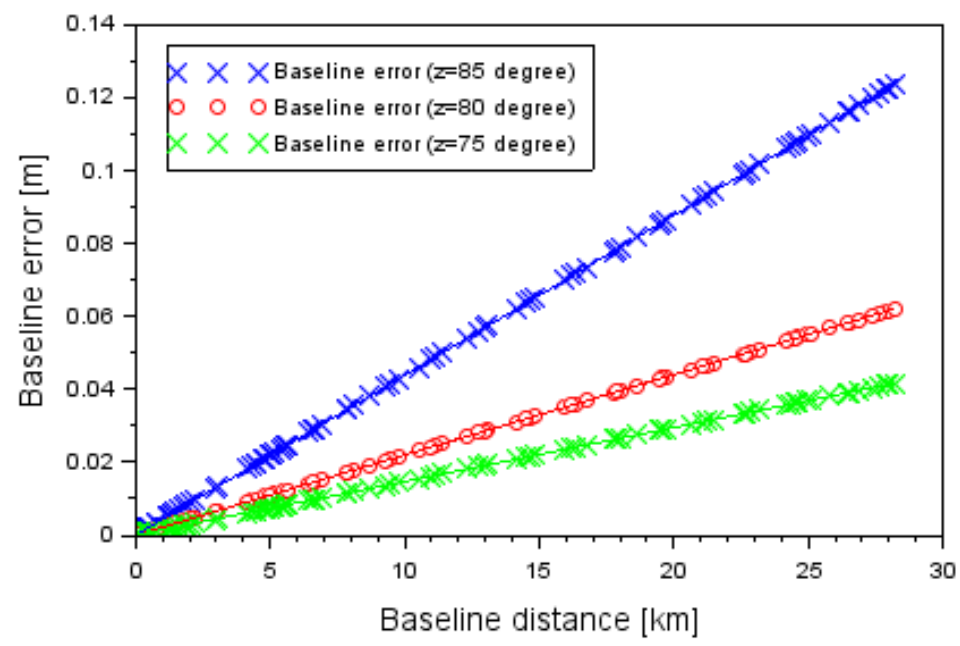

Fig. 3. The baseline error as a distance function for vector of base reference station-Cessna aircraft [based on Scilab software]

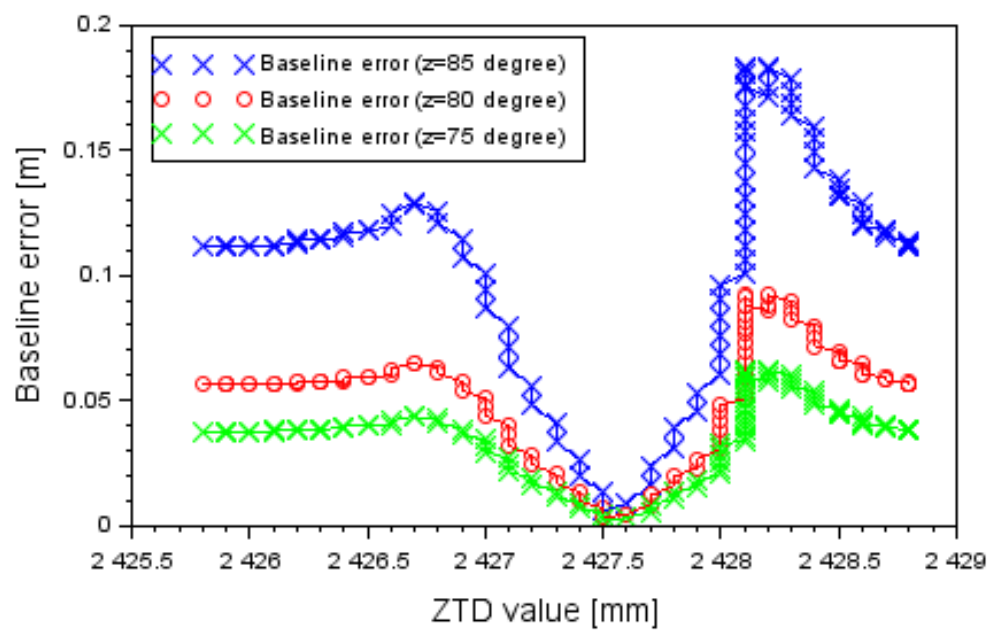

Fig. 4. The baseline error as a function of ZTD parameter for vector of VirA reference station-Cessna aircraft [based on Scilab software] 


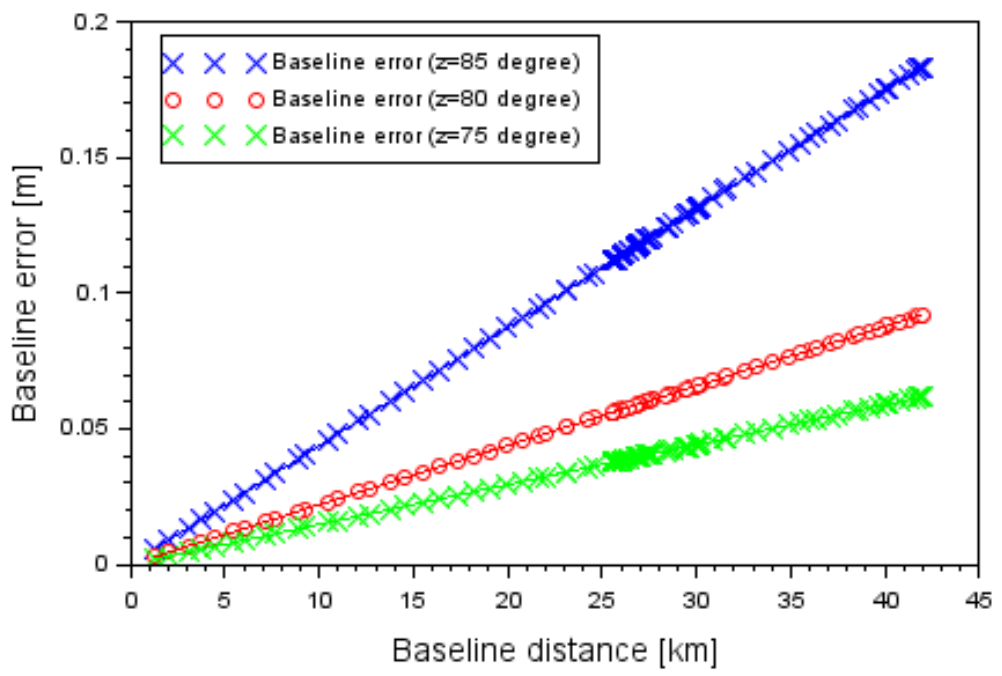

Fig. 5. The baseline error as a distance function for vector of VirA reference station-Cessna aircraft [based on Scilab software]

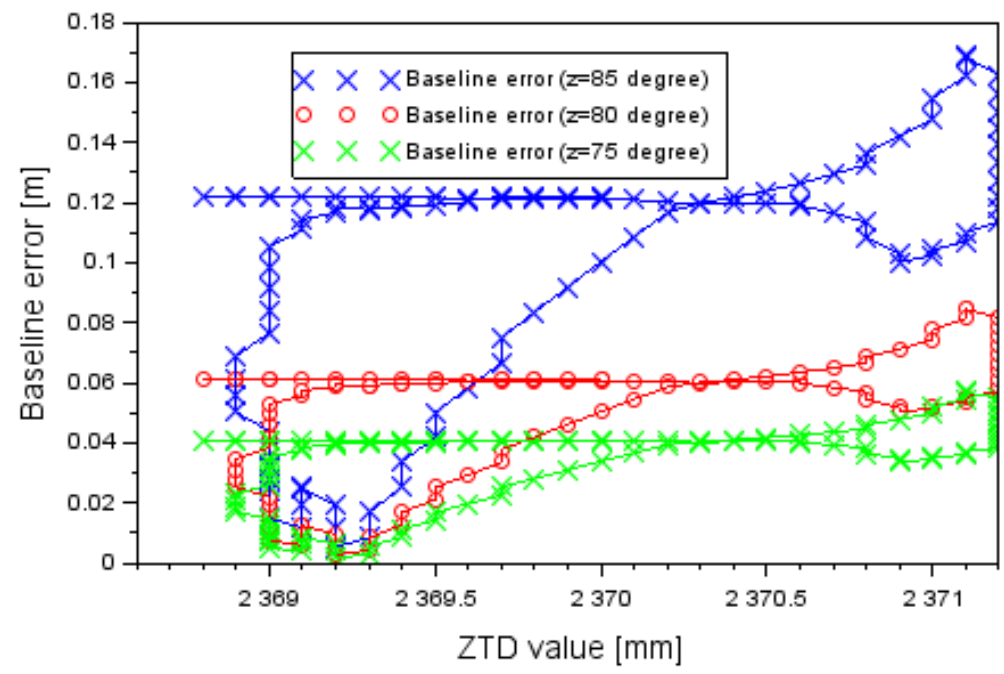

Fig. 6. The baseline error as a function of ZTD parameter for vector of VirB reference station-Cessna aircraft [based on Scilab software]

Figure 6 shows the results of determining the baseline measurement error between the reference station VirB and the GNSS on-board receiver. The values of the vector measurement error are presented in the function of the ZTD parameter. It can be concluded that the biggest error measurement of vector $r_{\text {Cessna-VirB }}$ arises when the ZTD is equal to $2371.1 \mathrm{~mm}$. Then, for the zenith angle $z=85^{\circ}$, the parameter $d r$ exceeds $0.169 \mathrm{~m}$. Moreover, 
at $z=80^{\circ}$ the $d r$ is equal to $0.085 \mathrm{~m}$. In addition, at $z=75^{\circ}$ the vector error $d r$ is equal to $0.057 \mathrm{~m}$. It is worth adding that the average value of the error of vector $d r$ for the zenith angle $z=85^{\circ}$ equals $0.099 \mathrm{~m}$, and for the angle $z=80^{\circ}$ it is equal to $0.050 \mathrm{~m}$, whereas for the zenith angle $z=75^{\circ}$, it is $0.034 \mathrm{~m}$.

Figure 7 shows the results of determining the error measurement of vector $r_{\text {Cessna-VirB }}$ in the distance function: reference station - GNSS on-board receiver. The biggest vector error for the baseline $r_{\text {Cessna-VirB }}$ is visible when the value $r_{\text {Cessna-VirB }}$ exceeds $39.6 \mathrm{~km}$. The reliance of the vector error $d r$ on its length $r_{\text {Cessna-VirB }}$ is a linear dependence, as shown in fig. 7. The minimum value of the error of vector $d r$ is visible when the distance $r_{\text {Cessna-VirB }}$ is equal to approximately $1.2 \mathrm{~km}$. In fig. 7, it is possible to observe that an increase in the zenith angle for large distances $r_{\text {Cessna-VirB }}$ has a direct impact on the results of the parameter $d r$.

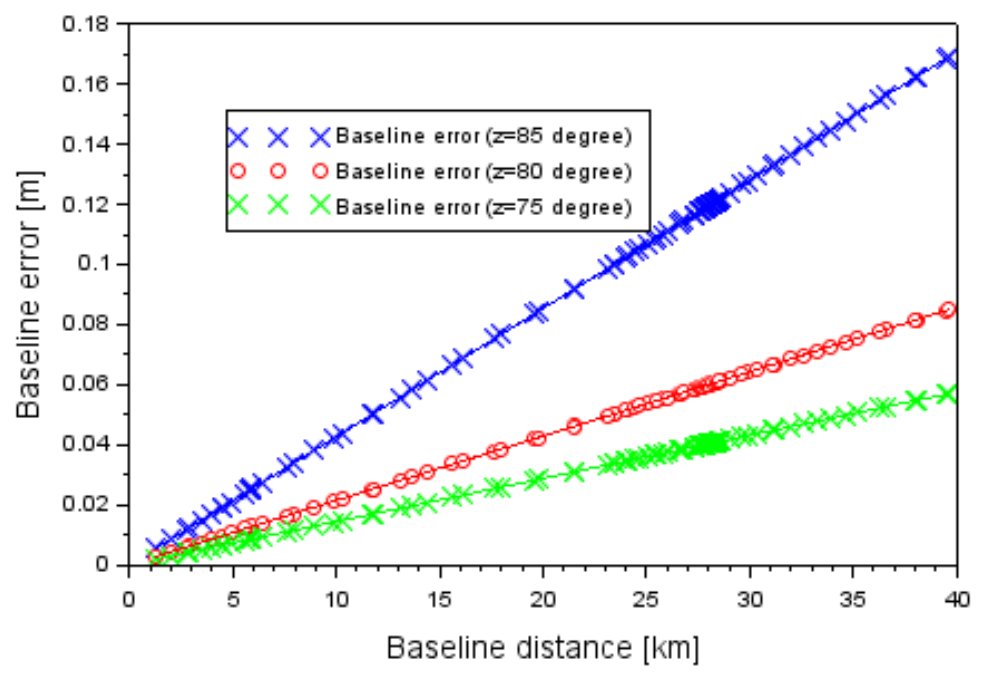

Fig. 7. The baseline error as a distance function for vector of VirB reference station-Cessna aircraft [based on Scilab software]

\section{Conclusion}

The paper specifies and determines the accuracy of the vector measurement between a reference station and a GNSS on-board receiver after taking into consideration the ZTD tropospheric delay factor. The computed error results of vector measurement exert a direct influence on the designation of an aircraft position in the horizontal plane within LNAV navigation. The entire calculations are crucial for the application of the RTK-OTF differential technique [5] within the GBAS augmentation technique in aviation. In case of using the RTK-OTF differential technique for the determination of the accurate aircraft position, the measurement errors of the vector, designated in this work, in accordance with 
the propagation of the mean errors of the measurement, affect the estimated aircraft coordinates. Hence, the obtained results of measurement accuracy of the vector between a reference station and a GNSS receiver may be applied when dealing with the concept of designing the GBAS system in Polish aviation, particularly, taking into account that in this manuscript, actual GNSS data, registered by an on-board receiver and individual reference stations, were used. Another important element of the work was to show dependence between designating the vector error and the influence of the ZTD tropospheric correction, taking into account the fact that the work is experimental, scientific and may find application in the aerospace industry.

On the basis of the obtained findings, it appears that the highest value of the vector error between the reference station and the GNSS on-board receiver can exceed $0.18 \mathrm{~m}$, for a distance of over $40 \mathrm{~km}$ and the $Z T D$ value equal to $2428.1 \mathrm{~mm}$. When the length of the vector is greater than $28 \mathrm{~km}$ and the $Z T D$ is equal to $2436.7 \mathrm{~mm}$, the vector error exceeds $0.12 \mathrm{~m}$. The results of the measurement error of vector are large and must be analysed by means of the RTK-OTF differential technique in the GBAS system.

In the future, the authors plan to conduct further research with regard to the determination of the impact of the ZTD tropospheric correction on the designation of an ellipsoidal altitude of an aircraft during an air operation. It should be emphasized that the impact of the ZTD tropospheric delay will concern absolute GNSS measurements (e.g. the method of absolute SPP and the PPP measurement technique) in aviation.

\section{Acknowledgement}

This paper was supported by the Military University of Aviation.

\section{References}

1. Beutler G., Bauersima I., Gurtner W., Rothacher M., Schildknechtt T., Geinger A.: Atmospheric refraction and other important biases in GPS carrier phase observations, in atmospheric effects on geodetic space measurements. Monograph 12. Kensington, Australia, 1987.

2. Fellner A.: Analysis of navigation systems and the framing of permanent stations RTK DGPS for aviation requirements, Habilitation Thesis, WSOSP, Dęblin 1999 (in Polish).

3. Fellner A., Śledziński J., Trómiński P., Zając J.: DGNSS/GIS POLPOS laboratory within the framework of European EUPOS System. Roczniki Geomatyki - Annals of Geomatics, Vol. 3, Iss. 1, 2005 (in Polish).

4. Fellner A., Jafernik H., Trómiński P.: RNAV GNSS essential step for the LUN implementation and the Chance for the polish GENERAL AVIATION. Prace Instytutu Lotnictwa - Transactions on Aerospace Research, 211(2), 2011 (in Polish). 
5. Grzegorzewski M., Ćwiklak J., Jafernik H., Fellner A.: GNSS for an Aviation. TransNav International Journal on Marine Navigation and Safety of Sea Transportation, Vol. 2, No. 4, 2008.

6. Grzegorzewski M., Ciećko A., Oszczak S., Popielarczyk D.: Autonomous and EGNOS Positioning Accuracy Determination of Cessna Aircraft on the Edge of EGNOS Coverage, Proceedings of the 2008 National Technical Meeting of The Institute of Navigation, San Diego, CA, January 2008.

7. Guo Q.: Precision comparison and analysis of four online free PPP services in static positioning and tropospheric delay estimation. GPS Solutions, 19, DOI: 10.1007/s10291-014-0413-5, 2015.

8. INTERNATIONAL CIVIL AVIATION ORGANIZATION: ICAO Standards and Recommended Practices (SARPS). Annex 10, Vol. I (Radionavigation aids), 2006. Polish version available at website: http://www.ulc.gov.pl/pl/prawo/prawomi $\% \mathrm{C} 4 \%$ 99dzynarodowe/206-konwencje, current on: 15.10.2018.

9. Kim M., Seo J., Lee J.: A comprehensive method for GNSS data quality determination to improve ionospheric data analysis. Sensors (Basel, Switzerland), 14(8), 2014, DOI: 10.3390/s140814971.

10. Krasuski K.: Utilization AUSPOS service for determination of reference station coordinates. Zeszyty Naukowe, Vol. 30, No. 3, 2016.

11. Mendez Astudillo J., Lau L., Tang Y. T., Moore T.: Analysing the Zenith Tropospheric Delay Estimates in On-line Precise Point Positioning (PPP) Services and PPP Software Packages. Sensors (Basel, Switzerland), 18(2), 580, 2018, DOI: 10.3390/s18020580.

12. Zhang Y., Wang Z.: The Impact of Tropospheric Anomalies on Sea-Based JPALS Integrity. Sensors, 18(8):2579, 2018, DOI: 10.3390/s18082579.

13. Zhao Q., Yao Y., Yao W., Li Z.: Real-time precise point positioning-based zenith tropospheric delay for precipitation forecasting. Scientific Reports, 8, 7939, 2018, DOI:10.1038/s41598-018-26299-3.

14. https://www.pansa.pl/?lang=_pl\&opis=wiecej\&id_wyslane=601, current on 2020 .

15. https://www.pansa.pl/?lang=_pl\&opis=wiecej\&id_wyslane=1191, current on 2020.

16. https://dlapilota.pl/wiadomosci/polska/international-gbas-working-group-w-krakowie, current on 2020.

17. https://apps.gdgps.net/apps/apps_file_upload.php, current on 2020.

18. https://www.scilab.org/, current on 2020 . 